\title{
Metabolic Syndrome. Particularities During SARS-CoV-2 Infection
}

\author{
Ana-Maria CIOTI', Ioana Veronica GRAJDEANU1,2, Anca Angela SIMIONESCU³, Cristian Gabriel \\ BEJAN², Ana Maria Alexandra STANESCU²
}

\begin{abstract}
The COVID-19 pandemic is a significant public health crisis as the coronavirus continues to rapidly spread with long-term socioeconomic consequences. Another malady, although non-transmissible, also a significant health hazard is the metabolic syndrome, which has widespread globally, being classified as an epidemic as the western lifestyle expands worldwide. The SARS-CoV-2 causes systemic inflammation similar to obesity; nevertheless, the coronavirus causes an unregulated rise in cytokine secretion, resulting in multiple organ failures and death. Increasing evidence demonstrates that obesity aggravates the COVID-19 disease and its mortality, the four most prevalent comorbidities of COVID-19 being hypertension, diabetes, cardiovascular, and respiratory disease, all of them tightly associated with obesity. This paper reviews the physiopathological processes that constitute the metabolic syndrome and the molecular mechanisms through which the coexistence of MetS can contribute to the pathogenicity of COVID-19 and an unfavorable outcome of the disease.
\end{abstract}

Keywords: COVID-19, SARS-CoV-2, metabolic syndrome, obesity, DM II, hypertension.

\section{Rezumat}

Pandemia COVID-19 este o criză semnificativă de sănătate publică, deoarece coronavirusul continuă să se răspândească rapid, cu consecințe socio-economice pe termen lung. O altă boală, deși netransmisibilă, de asemenea un pericol semnificativ pentru sănătate este sindromul metabolic, care s-a răspândit la nivel global, fiind clasificat ca o epidemie pe măsură ce stilul de viată occidental se extinde în întreaga lume. SARS-CoV-2 provoacă inflamatii sistemice similare cu obezitatea; cu toate acestea, coronavirusul provoacă o creștere nereglementată a secreției de citokine, ducând la eșecuri multiple de organe și la moarte. Dovezi din ce în ce mai mari demonstrează că obezitatea agravează boala COVID-19 și mortalitatea acesteia, cele patru cele mai răspândite comorbidități ale COVID-19 fiind hipertensiunea, diabetul, bolile cardiovasculare și respiratorii, toate strâns asociate cu obezitatea.

Această lucrare analizează procesele fiziopatologice care constituie sindromul metabolic și mecanismele moleculare prin care coexistența MetS poate contribui la patogenitatea COVID-19 și la un rezultat nefavorabil al bolii.

Cuvinte cheie: COVID-19, SARS-CoV-2, sindrom metabolic, obezitate, DM II, hipertensiune.

"Dr. Ioana Veronica Grajdeanu" Private Medical Practice, Bucharest, Romania

"Department of Family Medicine, "Carol Davila" University of Medicine and Pharmacy, Bucharest, Romania

${ }^{3}$ Department of Obstetrics and Gynecology, Filantropia Clinical Hospital, "Carol Davila" University of Medicine and Pharmacy, Bucharest, Romania
Corresponding author:

Ioana Veronica GRAJDEANU, „Dr. Ioana Veronica Grajdeanu”

Private Medical Practice, Bucharest, Romania.

E-mail: ioana.grajdeanu@umfcd.ro 


\section{INTRODUCTION}

Since the emergence of the first cases of infection in Wuhan, China, in December 2019, the SARS-CoV-2 virus has spread globally, and on March 11, 2019, the WHO classified the SARS-CoV-2 infection as a pandemic. A WHO report on SARS-CoV-2 indicates that as of 01.05.2021, there were over 155 million cases of infections and over 3 million deaths. The SARS-CoV-2 pandemic poses a devastating challenge to health systems around the world and the global economy ${ }^{1}$.

Metabolic syndrome (MS), also known as X syndrome, is defined by the WHO as a pathological condition characterized by abdominal obesity, insulin resistance, hypertension, and dyslipidemia. MetS is clinically diagnosed by the simultaneous presence of three or more of these pathologies, which are correlated due to overlapping metabolic pathways and pathophysiological mechanisms that coincide ${ }^{2}$. MS is a plethora of cardiovascular risk factors, including abdominal obesity, high blood pressure, impaired glucose tolerance, atherogenic dyslipidemia, pro-thrombotic status and pro-inflammatory status ${ }^{2,3}$.

Obesity is one of the leading causes of MetS and can contribute to the development of type 2 diabetes (T2DM), stroke, cardiovascular disease, and hypertension. According to the $\mathrm{WHO}$, the obesity rate has tripled since 1975, with over 650 million adults being obese in 2016. Surprisingly, by 2050 the overall global obesity rate is expected to exceed the majority of the adult population ${ }^{4,5}$.

Research demonstrates a strong clinical correlation between MetS and COVID-19 as increased hospitalization, severe progression, and poor clinical outcomes and mortality rates seem to correlate with risk factors such as obesity, hypertension, DM, cardiovascular disease ${ }^{6}$.

Table 1. The 'harmonized' metabolic syndrome: criteria for clinical diagnosis ${ }^{7,8}$

\begin{tabular}{|c|c|}
\hline Parameter & Categorical cut-points \\
\hline - $\quad$ Elevated waist circumference & Population and country-specific definitions \\
\hline $\begin{array}{l}\text { Elevated triglycerides } \\
\text { Drug treatment for elevated triglycerides is an alternative indicator }\end{array}$ & $\geq 150 \mathrm{mg} / \mathrm{dL}(1.7 \mathrm{mmol} / \mathrm{L})$ \\
\hline $\begin{array}{l}-\quad \text { Reduced HDL cholesterol } \\
\text { Drug treatment for reduced HDL-C is an alternative indicator }\end{array}$ & $\begin{array}{l}\text { Males: }<40 \mathrm{mg} / \mathrm{dL}(1.0 \mathrm{mmol} / \mathrm{L}) \\
\text { Females: }<50 \mathrm{mg} / \mathrm{dL}(1.3 \mathrm{mmol} / \mathrm{L})\end{array}$ \\
\hline $\begin{array}{l}\text { - Elevated blood pressure } \\
\text { Antihypertensive drug treatment in patients with a history of hypertension is an } \\
\text { alternative indicator }\end{array}$ & $\begin{array}{l}\text { Systolic } \mathrm{BP} \geq 130 \\
\text { Diastolic } \mathrm{BP} \geq 85 \mathrm{mmHg}\end{array}$ \\
\hline $\begin{array}{l}\text { - Elevated fasting plasma glucose } \\
\text { Drug treatment for hyperglycemia is an alternative criterion }\end{array}$ & $\geq 100 \mathrm{mg} / \mathrm{dL}(5.6 \mathrm{mmol} / \mathrm{L})$ \\
\hline
\end{tabular}

WHO acknowledges two levels of abdominal obesity in Europids (men of European descendence from the Middle East, Eastern Mediterranean region, and Sub-Saharan Africa) depending on the risk for metabolic complications. Increased risk occurs at waist circumferences of $\geq 94 \mathrm{~cm}$ in men and $\geq 80 \mathrm{~cm}$ in women, but the risk is substantially higher at $\geq 102 \mathrm{~cm}$ in men and $\geq 88 \mathrm{~cm}$ in women. The higher thresholds are used to define abdominal obesity in the United States, Canada, Europe and are also used as the waist circumference cut points to diagnose $\mathrm{MetS}^{8}$.

\section{ADIPOSE TISSUE IN OBESITY}

The adipose tissue (AT) has a dynamic endocrine role as it secrets a diversity of cell signaling cytokines, 
known as adipokines, which regulate local and systemic inflammation and energy homeostasis in normal, insulin-sensitive adipocytes.

Healthy adipose tissue has a complex and heterogeneous composition that includes adipocytes and several types of stromal cells, including fibroblasts, adipose-derived stem cells (ASCs), endothelial cells, and a variety of immune cells, such as resident macrophages, mast cells, monocytes, dendritic cells, natural killer cells, B cells, T cells, neutrophils, and eosinophils 9 .

Obesity remodels the adipose tissue through hypertrophy and hyperplasia of the adipocytes, leading to hypoxia of the adipose tissue, apoptosis of adipocytes, and an increased secretion of inflammatory adipokines, cytokines, and chemokines ${ }^{6}$. This results in a massive infiltration of proinflammatory cytokines that stimulate lipolysis and fuel insulin resistance, leading to adipocyte dysfunction and systemic disruptions of metabolism ${ }^{10}$. Ergo, the AT develops a local low-grade inflammatory microenvironment that attracts M1 inflammatory macrophages, T-cells, B-cells, neutrophils, and mast cells, whereas populations of type 2 helper T-cells (TH2), macrophage $\mathrm{M} 2$, and regulatory $\mathrm{T}$-cells (Treg) decrease as the levels of obesity progress ${ }^{6}$. As AT expands in obesity, the regulatory anti-inflammatory, immune state maintained by immunoregulatory cytokines including interleukin-4 (IL-4), IL-5, IL-10, IL-13, and IL-33 converts to a highly inflammatory state causing the secretion of monocyte chemoattractant protein-1 (MCP1 ), tumor necrosis factor $\alpha$ (TNF- $\alpha$ ), IL-1 $\beta$, interferon $\gamma($ IFN- $\gamma$ ), and IL-6, promoting a local as well as chronic systemic inflammation and metabolic dysfunction ${ }^{11}$. The secretion of these proinflammatory cytokines is mediated by the NLRP3 inflammasome, which plays a critical role in immune responses, glucose homeostasis, lipid metabolism, and adipocyte functions ${ }^{12}$.

\section{NLRP3 INFLAMMASOME, METABOLIC DISORDERS, AND PYROPTOSIS}

The NLRP3 inflammasome is a large multimolecular complex present in the cytosol of stimulated immune cells such as monocytes, macrophages, and dendritic cells. Activation of NLRP3 inflammasome is the most significant component of the innate immune response, crucial in the host defense against pathogens such as bacteria, fungi, or viruses. On the other hand, the NLRP3 inflammasome has been associated with met- abolic and inflammatory conditions such as T2DM, insulin resistance, atherosclerosis, obesity, gout, and neurodegenerative diseases ${ }^{13,14}$.

Once activated, the NLRP3 inflammasome will induce pyroptosis, an inflammatory form of programmed cell death through the assembly of plasma membrane pores by members of the gasdermin (GSDM) protein family into the macrophage cell membrane as a consequence of inflammatory caspase activation. This process disrupts the osmotic potential of the cell membrane and releases cytosolic content causing systemic dissemination of pro-inflammatory molecules ${ }^{14}$.

Activation of the NLRP3 inflammasome impacts the development of T2DM and its complications, as overexpression of IL-1 $\beta$ consequently causes dysregulation of glycemic control. In hepatocytes and adipocytes, the IL$1 \beta$ cytokine interferes with insulin signaling, inhibiting insulin-induced glucose uptake, suppressing lipogenesis, and reducing adiponectin release. The pancreatic islets are affected by the IL-1 $\beta$ cytokine, which reduces insulin secretion, impairs $\beta$-cell replication, and increases $\beta$-cell apoptosis. Furthermore, IL-1 $\beta$ promotes tumor necrosis factor-alpha (TNF- $\alpha$ ), a cytokine known to increase insulin resistance ${ }^{15,16}$.

The NLRP3 inflammasome is also involved in the pathogenesis of atherosclerosis, which is characterized by an intricate interaction between macrophages, endothelial cells, and smooth muscle cells ${ }^{13}$. The endothelium controls vascular homeostasis by preserving a careful balance between vasodilators and vasoconstrictors secretion and producing bioactive mediators regulating vascular tone, permeability, proliferation, and smooth muscle cell migration, leukocyte migration, and platelet adhesion and aggregation ${ }^{17}$. Atherosclerotic cardiovascular disease is the leading cause of mortality worldwide and a significant consequence of MetS.18 Impaired lipid metabolism, specifically elevated levels of plasma LDL-cholesterol contributes to the formation of atherosclerotic plaques. Intracellular cholesterol-carrying lipoprotein (oxLDL) is converted into cholesterol crystals causing NLRP3 inflammasome activation. Normal vascular smooth muscle cells become dysfunctional due to the release of mature IL$1 \beta$ that leads to platelet aggregation and activation of inflammatory cells. Consequently, IL-1 $\beta$ and IL-18 secretion skyrocket, disrupting endothelial hemostasis by aggravating and amplifying the inflammatory response and contributing to the rising morbidity of cardiovascular and cerebrovascular diseases ${ }^{13}$. 


\section{COVID-19, NLPR3 INFLAMMASOME AND PYROPTOSIS}

The agent responsible for COVID-19 is known as the severe acute respiratory syndrome coronavirus 2 (SARS-CoV-2). It is an enveloped single-stranded positive-sense RNA virus studded with spike (S), membrane (M), and envelop (E) proteins ${ }^{14}$. SARS$\mathrm{CoV}-2$ enters target cells via its viral spike (S) protein, which binds to its functional receptor human angiotensin-converting enzyme 2 (ACE2). The ACE2 protein is present in arterial smooth muscle cells in all organs, including oral and nasal mucosa, nasopharynx, stomach, colon, liver, kidney, and brain, with a unique expression of ACE2 protein on lung alveolar epithelial cells, small intestine enterocytes, and endothelial cells ${ }^{19}$. ACE2 is also highly expressed in AT, and its expression increases with obesity, making AT a potential target organ for SARS-CoV-2 and its viral reservoir ${ }^{2}$. NLRP3 Inflammasome activation triggered by viral internalization induces pyroptosis and results in a massive release of TNF- $\alpha$, IFN- $\gamma$, IL-1 $\beta$, IL-8, MCP-1, and IP-10 as seen in the acute phase of COVID-19 patients. It has been suggested that the viral reservoir could act as a catalyst, boosting intense inflammation, fueling an exacerbated immune response, damaging tissues, and causing multi-organ failure, all of which are severe COVID-19 complications.

SARS-CoV-2 depends on furin-mediated pre-cleavage of its spike protein at the $\mathrm{S} 1 / \mathrm{S} 2$ site, proteolysis that initiates the process of cellular entry. Furin is also highly expressed in obese AT as well as during adipogenesis. Furin not only supports the entry of SARS-CoV-2 into cells by priming the spike protein but also the release of new viral particles, allowing them to enter circulation and invade the neighboring cells ${ }^{6},{ }^{21}$.

\section{OBESITY AND CYTOKINE STORM IN COVID-19}

Like obesity, SARS-CoV-2 also induces systemic inflammation, but it can determine an aggressive immune response known as cytokine storm or cytokine release syndrome in critically ill patients. The cytokine storm is characterized by an uncontrolled increase of cytokine secretion, with detrimental effects causing multiple organ failure followed frequently by death. The pre-existing systemic inflammatory state in obese patients can be boosted or accelerated during SARS-CoV-2 infection by activating the NLRP3 inflammasome and the release of pro-inflammatory cytokines through Gasdermin-pores after pyroptosis ${ }^{14}$.

Cytokine storm appears to be important in COVID-19 patients when it comes to the pathogenesis of several severe forms of the disease: acute respiratory distress syndrome, thromboembolic events such as acute ischemic strokes or myocardial infarction, encephalitis, acute kidney injury, and vasculitis (Kawasaki-like syndrome in children and renal vasculitis in adult $)^{14}$.

\section{MECHANISMS FOR INCREASED SARS-COV-2 INFECTION SEVERITY IN METS}

Several studies have shown a close connection between COVID-19 and MetS. Obese COVID-19 patients with impaired metabolic health have a higher hospitalization rate, a faster progression, and worse health outcomes. At least five aspects link obesity, diabetes, and COVID-19: viral load, immune response, alveolar dysfunction, endothelial dysfunction, and coagulopathy ${ }^{6}$.

SARS-CoV-2 viral load may be increased through an effective cellular entry mediated by ACE2 receptors. An overexpression of ACE2 was detected in the AT of obese patients and the lung, kidney, and heart tissue of diabetic mice ${ }^{22}$.

The efficient clearance of viral load in all viral infections depends on the coordinated actions of the innate and adaptive immune system. Obesity and diabetes impair the immune response, and both are correlated to chronic low-level inflammation, decreased NK cell function, and deregulated numbers of CD4+ and CD8+ T cells, all of which could lead to a delayed immune response and sustained hyper inflammation in COVID-19 patients $^{22}$.

Individuals with T2DM have substantially lower pulmonary function parameters such as forced vital power, total lung capacity, alveolar membrane permeability, and alveolar gas exchange ${ }^{22}$. Obesity has a wide range of adverse effects on lung function, weakening the lung defenses against SARS-CoV-2. The respiratory volumes are decreased, the systemic inflammation alters microvascular permeability, damaging endothelial cells and leading to airway obstruction. Expanding AT around the pulmonary artery alongside systemic 


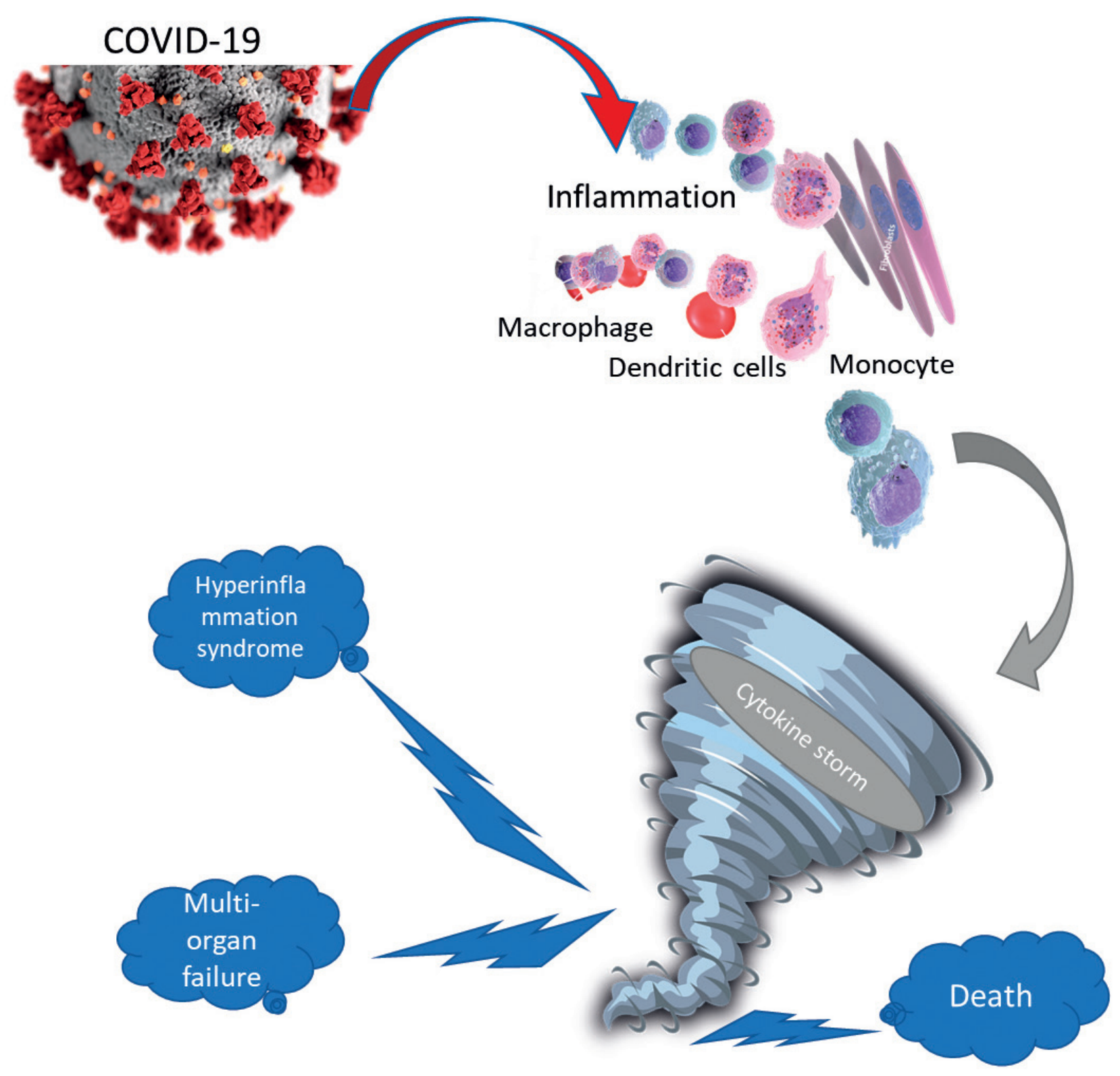

Figure 1. Cytokine storm in COVID-19

inflammation, insulin resistance, and oxidative stress can lead to pulmonary arterial hypertension ${ }^{6,23}$.

Patients with diabetes during SARS-CoV-2 infection are more likely to develop endothelitis due to increased vascular lesions, endothelial inflammation, and vasoconstriction correlated with previous endothelial dysfunction.22 SARS-CoV-2 infection could initiate endothelial inflammation in several organs, and pyroptosis may have an essential role in endothelial cell injury and host inflammatory response contributing to the cytokine storm and pulmonary lesions ${ }^{6}$.
Obesity promotes the development of hypertension by damaging the endothelium and causing systemic inflammation. Furthermore, morbidly obese patients have higher serum renin levels, angiotensinogen, $\mathrm{ACE}$, Ang II, and aldosterone, activating the renin-angiotensin-aldosterone mechanism leading to the development of hypertension and cardiovascular disease ${ }^{24}$. The myocardium is also affected by SARS-CoV-2-induced endothelitis and microvascular dysfunction. The cytokine storm observed in severe COVID-19 cases is thought to cause vascular inflammation and atheroscle- 
rotic plaque instability, and myocardial inflammation. Therefore, patients with COVID-19 can develop cardiovascular complications such as acute coronary syndrome, an acute myocardial injury without obstructive coronary artery disease, arrhythmias, heart failure, pericardial effusion, or thromboembolic complications ${ }^{25}$.

Severely ill COVID-19 patients are often associated with increased systemic coagulation and obesity as well as diabetes are characterized by a prothrombotic status ${ }^{26}$. In obesity, the hypercoagulable state is correlated with the overexpression of multiple proteins associated with coagulation like thrombin, fibrinogen, coagulation factors (FXa, FVIIa, and FV), and activated protein $\mathrm{C}$ in diverse cell types including adipocytes, endothelial cells, and vascular smooth muscle cells ${ }^{27}$. COVID-19 disease in patients with obesity and impaired metabolic health exacerbates the clotting disorders, as acute hyperglycemia and hyperinsulinemia were shown to trigger coagulation and fibrinolytic activity during the inflammatory response ${ }^{22}$.

\section{CONCLUSIONS}

The simultaneous presence of underlying chronic conditions such as hypertension, obesity, or cardiovascular diseases together with altered ACE2 receptor expression, immune dysregulation, alveolar and endothelial dysfunction, and increased systemic coagulation may put individuals with metabolic syndrome at risk for severe forms of COVID-19.

Compliance with ethics requirements: The authors declare no conflict of interest regarding this article. The authors declare that all the procedures and experiments of this study respect the ethical standards in the Helsinki Declaration of 1975, as revised in 2008(5), as well as the national law. Informed consent was obtained from all the patients included in the study.

Acknowledgement: All authors have equal contributions.

\section{References}

1. WHO. WHO Coronavirus Disease (COVID-19) Dashboard; World Health Organization: Geneva, Switzerland, 2021. Accessed May 10, 2021 https://covid19.who.int/

2. Saklayen MG. The Global Epidemic of the Metabolic Syndrome. Curr Hypertens Rep. 2018 Feb 26;20(2):12. doi: 10.1007/s1 1906018-0812-z.

3. Bansal R, Gubbi S, Muniyappa R. Metabolic Syndrome and COVID 19: Endocrine-Immune-Vascular Interactions Shapes Clinical Course. Endocrinology. 2020 Oct 1;161(10):bqaa112. doi: 10.1210/endocr/bqaa112.

4. Smith M, Honce R, Schultz-Cherry S. Metabolic Syndrome and Viral Pathogenesis: Lessons from Influenza and Coronaviruses. J Virol. 2020 Aug 31;94(18):e00665-20. doi: 10.1128/JVI.0066520.

5. WHO. Obesity and overweight. Accessed May 10, 2021. https:// www.who.int/news-room/fact-sheets/detail/obesity-and-overweight

6. Ritter A, Kreis NN, Louwen F, Yuan J. Obesity and COVID-19: Molecular Mechanisms Linking Both Pandemics. Int J Mol Sci. 2020 Aug 12;21(16):5793. doi: 10.3390/ijms21165793.

7. Nilsson PM, Tuomilehto J, Rydén L. The metabolic syndrome What is it and how should it be managed? Eur J Prev Cardiol 2019 Dec;26(2_suppl):33-46. doi: 10.1177/2047487319886404.

8. Alberti KG, Eckel RH, Grundy SM, Zimmet PZ, Cleeman JI, Donato KA, Fruchart JC, James WP, Loria CM, Smith SC Jr; International Diabetes Federation Task Force on Epidemiology and Prevention; Hational Heart, Lung, and Blood Institute; American Heart Association; World Heart Federation; International Atherosclerosis Society; International Association for the Study of Obesity. Harmonizing the metabolic syndrome: a joint interim statement of the International Diabetes Federation Task Force on Epidemiology and Prevention; National Heart, Lung, and Blood Institute;

American Heart Association; World Heart Federation; International Atherosclerosis Society; and International Association for the Study of Obesity. Circulation. 2009 Oct 20;120(16):1640-5. doi: 10.1161/CIRCULATIONAHA.109.192644. Epub 2009 Oct 5.

9. Lu J, Zhao J, Meng H, Zhang X. Adipose Tissue-Resident Immune Cells in Obesity and Type 2 Diabetes. Front Immunol. 2019 May 22;10:1173. doi: 10.3389/fimmu.2019.01173.

10. Grant RW, Stephens JM. Fat in flames: influence of cytokines and pattern recognition receptors on adipocyte lipolysis. Am J Physiol Endocrinol Metab. 2015 Aug 1;309(3):E205-13. doi: 10.1152/ ajpendo.00053.2015.

11. Exley MA, Hand L, O'Shea D, Lynch L. Interplay between the immune system and adipose tissue in obesity. J Endocrinol. 2014 Nov;223(2):R41-8. doi: 10.1530/JOE-13-0516.

12. Vandanmagsar B, Youm YH, Ravussin A, Galgani JE, Stadler K, Mynatt RL, Ravussin E, Stephens JM, Dixit VD. The NLRP3 inflammasome instigates obesity-induced inflammation and insulin resistance. Nat Med. 2011 Feb;17(2):179-88. doi: 10.1038/ nm.2279.

13. Jiang D, Chen S, Sun R, Zhang X, Wang D. The NLRP3 inflammasome: Role in metabolic disorders and regulation by metabolic pathways. Cancer Lett. 2018 Apr 10;419:8-19. doi: 10.1016/j. canlet.2018.01.034

14. López-Reyes A, Martinez-Armenta C, Espinosa-Velázquez R, Vázquez-Cárdenas $\mathrm{P}$, Cruz-Ramos $\mathrm{M}$, Palacios-Gonzalez $\mathrm{B}$, Gomez-Quiroz LE, Martínez-Nava GA. NLRP3 Inflammasome: The Stormy Link Between Obesity and COVID-19. Front Immunol. 2020 Oct 30;11:570251. doi: 10.3389/fimmu.2020.570251.

15. Gora IM, Ciechanowska A, Ladyzynski P. NLRP3 Inflammasome at the Interface of Inflammation, Endothelial Dysfunction, and Type 2 Diabetes. Cells. 2021 Feb 3;10(2):314. doi: 10.3390/ cells 10020314 
16. Dinarello CA, Donath MY, Mandrup-Poulsen T. Role of IL-1beta in type 2 diabetes. Curr Opin Endocrinol Diabetes Obes. 2010 Aug;17(4):314-21. doi: 10.1097/MED.0b013e32833bf6dc.

17. Kwaifa IK, Bahari H, Yong YK, Noor SM. Endothelial Dysfunction in Obesity-Induced Inflammation: Molecular Mechanisms and Clinical Implications. Biomolecules. 2020 Feb 13;10(2):291. doi: 10.3390/biom10020291.

18. Barquera S, Pedroza-Tobías A, Medina C, Hernández-Barrera L, Bibbins-Domingo K, Lozano R, Moran AE. Global Overview of the Epidemiology of Atherosclerotic Cardiovascular Disease. Arch Med Res. 2015 Jul;46(5):328-38. doi: 10.1016/j.arcmed.2015.06.006.

19. Varga Z, Flammer AJ, Steiger P, Haberecker $M$, Andermatt $R$, Zinkernagel AS, Mehra MR, Schuepbach RA, Ruschitzka F, Moch $\mathrm{H}$. Endothelial cell infection and endotheliitis in COVID-19. Lancet. 2020 May 2;395(10234):1417-1418. doi: 10.1016/S01406736(20)30937-5.

20. Kruglikov IL, Scherer PE. The Role of Adipocytes and Adipocyte-Like Cells in the Severity of COVID-19 Infections. Obesity (Silver Spring). 2020 Jul;28(7):1187-1190. doi: 10.1002/ oby. 22856 .

21. Johnson BA, Xie X, Kalveram B, Lokugamage KG, Muruato A, Zou J, Zhang X, Juelich T, Smith JK, Zhang L, Bopp N, Schindewolf C, Vu M, Vanderheiden A, Swetnam D, Plante JA, Aguilar P, Plante KS, Lee B, Weaver SC, Suthar MS, Routh AL, Ren P, Ku Z, An Z, Debbink K, Shi PY, Freiberg AN, Menachery VD. Furin Cleavage Site Is Key to SARS-CoV-2 Pathogenesis. bioRxiv [Preprint]. 2020 Aug 26:2020.08.26.268854. doi: 10.1101/2020.08.26.268854.
22. Erener S. Diabetes, infection risk and COVID-19. Mol Metab. 2020 Sep;39:101044. doi: 10.1016/j.molmet.2020.101044.

23. Ayinapudi K, Singh T, Motwani A, Le Jemtel TH, Oparil S. Obesity and Pulmonary Hypertension. Curr Hypertens Rep. 2018 Oct 5;20(12):99. doi: 10.1007/s11906-018-0899-2.

24. Hall JE, do Carmo JM, da Silva AA, Wang Z, Hall ME. Obesity-induced hypertension: interaction of neurohumoral and renal mechanisms. Circ Res. 2015 Mar 13;116(6):991-1006. doi: 10.1161/CIRCRESAHA.116.305697.

25. Stefan N, Birkenfeld AL, Schulze MB. Global pandemics interconnected - obesity, impaired metabolic health and COVID-19. Nat Rev Endocrinol. 2021 Mar;17(3):135-149. doi: 10.1038/s41574020-00462-1.

26. Connors JM, Levy JH. COVID-19 and its implications for thrombosis and anticoagulation. Blood. 2020 Jun 4;135(23):20332040. doi: $10.1182 /$ blood. 2020006000.

27. Madhusudhan T, Ruf W. Coagulation Signalling and Metabolic Disorders: Lessons Learned from Animal Models. Hamostaseologie. 2019 Jun;39(2):164-172. doi: 10.1055/s-0039-1688800. 